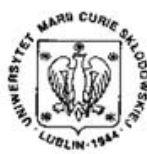

Annales UMCS Informatica AI X, 1 (2010) 167-175 DOI: $10.2478 / \mathrm{v} 10065-010-0046-4$

Annales UMCS

Informatica

Lublin-Polonia

Sectio AI

http://www.annales.umcs.lublin.pl/

\title{
Applications of multimedia devices as teaching aids
}

\author{
Tomasz Prauzner* \\ Institute of Technical Education, Jan Dtugosz University in Częstochowa \\ ul. Bohaterów Katynia 40/42, Częstochowa, Poland.
}

\begin{abstract}
The development of computer technology is reflected, among others, in the development of modern didactics. Current pedagogy and media education, as a fast developing discipline of general pedagogy, is a topic of a number of studies. Applying the modern multimedia aids at various stages and in various types of education is considered as an indispensable element of modern didactics, due to new opportunities the modern media offer. An interactive whiteboard is an example of such a modern teaching aid applied at present in education.
\end{abstract}

\section{Information Technology in the school}

Computers have become ubiquitous. They are applied in business, as home entertainment devices and as a teaching/learning aid. This fact cannot be disregarded in the education of the youth. The ability to operate personal computers and related IT devices is an indispensible skill in modern information society. For the young generation to develop the skill, they are to be regularly and permanently exposed to the latest achievements in technology. That is why it is vital to popularize the idea of information technology in the school in various forms and at various levels of education, from kindergarten to university.

It has to be noted that the education programmes and curricula, although developed by outstanding specialists, may become outdated before they actually reach the classroom. The publishing of textbooks may take even years so that teachers are often rightly concerned about the validity and currency of the textbook content.

*t.prauzner@ajd.czest.pl 
Sometimes, in the pursuit of their individual interests, students get updated about the latest scientific and technological findings by surfing the Internet. On the one hand, it is a positive phenomenon, on the other hand it makes educators think how to keep teaching curricula updated. This, in turn, implies further questions: how to pass on the knowledge by means of modern and more attractive teaching aids? In the light of the financial situation of the school system in Poland, it is not easy to find an answer to either of the questions. Fortunately, due to the unbelievable pace of the IT development, what is currently the most modern and expensive, will soon become cheaper and more available when new solutions appear. The dynamic character of the changes provides an opportunity for schools, most of which are equipped with IT labs, multimedia software and access to the Internet. It has to be kept in mind that some five or ten years ago the situation was different and few schools could pride themselves on having a modern IT lab.

As the time passes, the requirements that educational services have to meet evolve. Social changes following the economic ones created the demand for up-to date educated staff. Finding such employees may be a real challenge for an employer. Owing to that, it is essential to offer education in the fields in which specialists are sought. Besides, in the long-term perspective it turns out that the skills acquired at school are insufficient and education must therefore be continued in the form of lifelong learning. Both state and private educational institutions respond to this need, offering many courses financed by resources coming from EU projects. The development of the lifelong learning provides a unique opportunity to enhance, or to change qualifications.

Modern Information Technology helps develop students' abilities by boosting the following:

- learning - it enhances ways of gaining knowledge and skills, it facilitates problem-solving and decision-making, it integrates experiences and various elements of knowledge,

- thinking - it facilitates understanding phenomena in their full complexity and enables their holistic perception, it also boosts creativity,

- searching abilities - it helps to search, classify, and make use of information coming from various sources,

- ability to act - it improves the organization of work and facilitates the use of various techniques and tools, it develops a flexible attitude to one's qualification and a constant need to improve them;

- communication skills - it provides means for individual and group presentations and for effective communication thereby promoting unlimited contact among humans,

- co-operation - it helps working in a local or global group and reaching agreement, it can be used for making and sustaining contact and developing relationships. 


\section{Teaching aids in lifelong learning}

Lifelong learning makes use of the same teaching aids as regular school learning. Because of the character of lifelong learning, however, the most valuable teaching aids are those that enable access to the source of knowledge without the necessity to participate in group meetings. It is also important that the pace of learning can be individually adjusted to suit one's needs, abilities, and the amount of time available. Thus, lifelong learning very often takes the form of e-learning, which is characterized by an unconstrained choice of the educational institution, learning time and speed. The basic condition that has to be met for e-learning to take place is access to a computer and to the internet. It goes without saying that when we mention a computer, we mean a complete IT infrastructure including a video camera, sound transmission devices, multimedia projectors, etc. All the devices employed in e-learning are based on digital technology. The advantages of using a computer or a projector are rather obvious, so in the subsequent part of the paper I shall concentrate on novelties, which are seldom used, especially in secondary schools. The novelties include an interactive whiteboard or various kinds of accompanying devices, such as tablets.

\section{$3 \quad$ Interactive whiteboard}

The device is a relatively recent invention, which explains why there are few interactive whiteboards in schools: the price is too high. An interactive whiteboard is a valuable part of laboratory equipment and it can take a central place in an instructor's work, next to the traditional board, or, as has been occasionally claimed, it can even replace the traditional board. I myself do not necessarily subscribe to this view, since I believe that traditional teaching aids cannot be dispensed with and that the modern aids should be used as a means of making classes more attractive. In e-learning, however, the interactive whiteboard has a lot of advantages, which should be fully exploited. An interactive whiteboard can be seen in Fig. 1. A number of similar boards can be obtained on the market from various producers and sellers. Next to a multimedia projector and a computer, the board operates with electronic tablets enabling a student to observe what is being presented on the board, and what is more, to actively participate in the visual presentation of the topic discussed.

The tablet usually comes in two versions: for the teacher and for the student. A teacher's tablet makes it possible for the teacher to view test results on a colour LCD, and a student's tablet is equipped with a black-and-white display showing the battery charge level. The wireless technology enables connecting up to 30 tablets to one computer and working with 9 tablets at a time ${ }^{1}$. In this way, a multi-user system is created which is intended to support and increase students' motivation for group learning. Both the teacher and students can work on the same document at the same time. It is an ideal solution for activating the group, making simulations, or surveys.

\footnotetext{
${ }^{1}$ Parameters given by the producer Interwrite Learning for a specific model.
} 


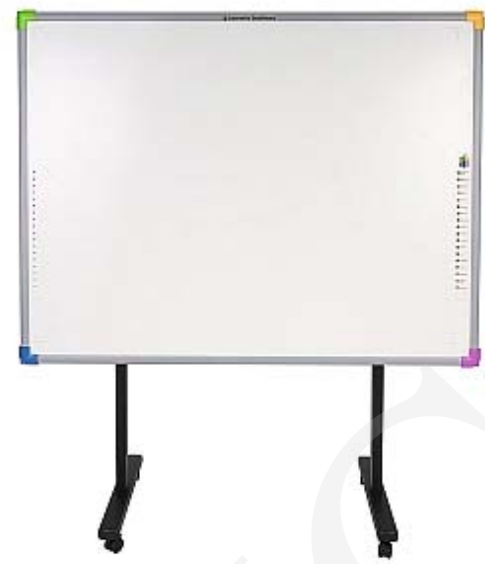

Fig. 1. An interactive whiteboard - Interwrite DualBoard (source: www.agraf.com.pl).

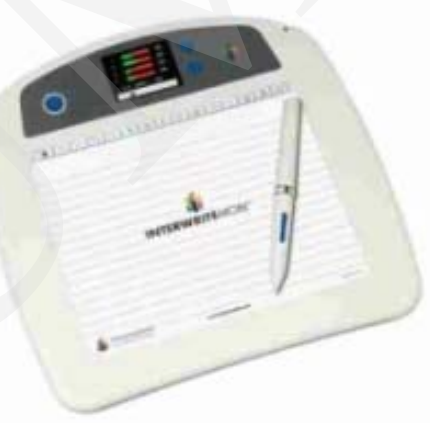

Fig. 2. Wireless tablet Interwite Mobi produced by Interwrite Learning.

The teacher's tablet provides a full, though discreet control over students' work. Due to the fact that the teacher can see answers entered by students on the display, s/he can assess the results immediately upon completing the task and discuss errors with particular students.

The wireless connection between the tablet and the board makes it possible for the teacher to add or alter information on the board from any place in the classroom. The same can be done in classrooms without an interactive whiteboard, as long as there is a computer, a projector, and any screen.

The interactive whiteboard operates as a touch screen, on which teachers and students can display the contents of computer files, or take notes. They can use it 
as an ordinary board, and subsequently save and print a text, pictures, etc. There are so many possibilities offered by the interactive whiteboard that they cannot be enumerated here. The most effective use of the device involves the use of a multimedia projector and a computer. Then, writing on the board with a pen is purely virtual and what is written is displayed by means of a projector ${ }^{2}$.

At present a number of companies compete against one another on the IT market, which provides an incentive for further development and enhancing the possibilities of interactive whiteboards. Some models are more technologically advanced than others but all of them have the same basic functions of an interactive whiteboard. Thus, selecting a particular model for educational purposes should be based on assessing its individual properties.

Interactive whiteboards have become an indispensable tool to be used in training courses, in teaching, and all sorts of presentations. The interactive whiteboards of the latest generation employ a wireless technology. They are characterized by an excellent quality of display and highly functional software ${ }^{3}$.

In schools nowadays, the most often used devices are computers and multimedia projectors.

Classes are conducted according to the schema below:

- Before the class teachers prepare didactic materials in the electronic form. Such materials can also be used for round-up lessons, exercises and tests. The materials can be printed out or displayed by means of a projector.

- Using a projector makes it possible to display text files with data or video files. It is also possible to present multimedia materials.

Using an interactive whiteboard opens a number of new possibilities:

- On the surface of an interactive whiteboard one can write with erasable markers or attach magnets to it. An interactive whiteboard can be mounted on the wall, next to, or instead of a traditional board, it can also be moved around the classroom on a floor stand.

- The computer in which the text or graphic files are stored can be connected to a projector. The files will be displayed on the board. Then, by means of an electronic pen one can write comments and notes directly on the board, which is not possible with the usual projector screen. When the whole surface available is covered with notes, it is moved upwards as in an ordinary text document. Thus, the writing surface on the board is unlimited.

- The interactive whiteboard has a function of saving the notes and comments written on it by means of an electronic pen. They are subsequently available at the computer disc. Teachers can use such applications as PowerPoint, Word and Excel, which do not require the Internet connection. Students can solve

\footnotetext{
${ }^{2}$ The company Systemy Prezentacji, http://www.systemyprezentacji.pl /tablice-interaktywne.html

${ }^{3}$ Interactive whiteboards StarBoard, http://www.hitachisoft.de/pl/produkt /Interaktywne_Tablice.php
} 
tasks and do exercises on the board, which makes their class participation more active ${ }^{4}$.

All the boards which are currently produced can work in a number of modes. There are usually three modes, which, combined with additional external devices, offer several possibilities to the teacher ${ }^{5}$.

(1) The CLASS mode i.e. interactive mode. It enables interactive work with the board and additional devices, such as tablets (see section 3). Each element of the interaction is displayed on the board or on some other surface so that every person participating in the interaction can observe the ongoing changes.

(2) The OFFICE mode - the user can work on such applications as PowerPoint, Microsoft Word and Excel. In this mode it is possible to add notes directly to the slide, document, or sheet. The notes are saved and stored as part of the original file.

(3) The WHITEBOARD mode is the simplest, since it requires only the board and a computer. When working in this mode, one makes notes, drawings and calculations by means of an electronic pen with a built-in marker on the board. All such notes, drawings, etc. will be saved as computer files so that a complete account of a meeting, lecture, or training session can be stored. No projectors are used, so data input to the computer are not to be retrieved and displayed on the board again. Whatever is written on the board with the marker will be displayed on the computer screen in the same colour as on the board. Also when using a marker with a protected tip for writing on the board, whatever is written will be displayed on the computer screen (though not on the board) in the colour in which the pen normally writes ${ }^{6}$.

As the characteristic above shows, the board offers possibilities which are not available for traditional classroom boards. Next to the obvious advantages, however, there are also drawbacks. Using the device during classes taught in the Institute of Technical Education at Jan Dlugosz University in Czestochowa I observed that the possibilities offered by the board are not always exploited to the full. This can be explained by several factors, such as:

- Being able to use the potential of the device requires knowledge about its operation as well as skills and practice in applying it. Training the staff in order to provide such knowledge and skills is highly advisable. Instructors teaching technical subjects do not show greater difficulties with operating the device but instructors teaching humanities generally do.

- The devices require careful servicing and maintenance. As electronic devices they also require frequent recharging of batteries for pens. Besides, the board itself has to be systematically calibrated by technicians.

\footnotetext{
${ }^{4}$ http://www.hitachisoft.de/pl/bildung/portal_lehrer.php?navid=3

${ }^{5}$ Opracowanie na podstawie analizy technicznej urzadzenia Interwrite DualBoard.

${ }^{6} \mathrm{http}: / /$ www.agraf.com.pl/index.php? $\mathrm{menu}=$ produkty $\&$ main $=$ product $\&$ product $=304 \& \operatorname{tab}=-1$
} 


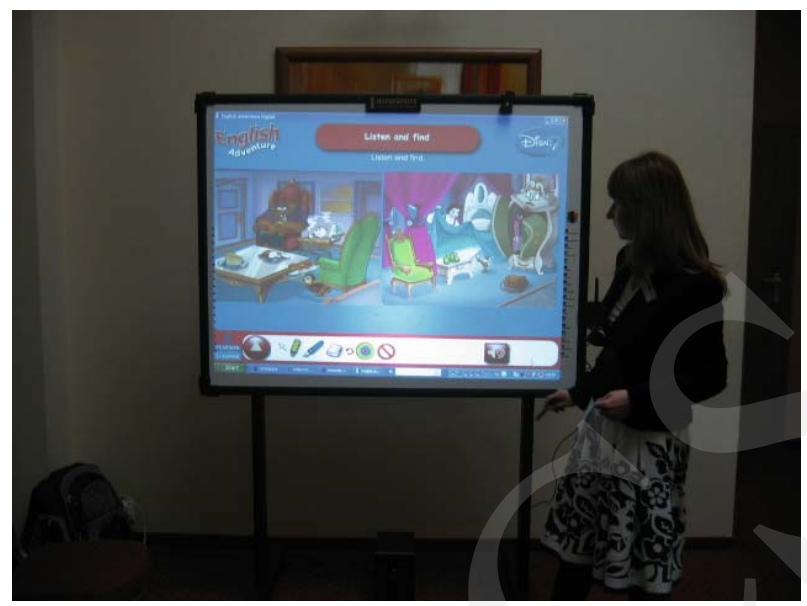

Fig. 3. Working with an interactive whiteboard with educational software (source: www.pomoceszkolne.pl).

- Although the devices are portable, an unforeseen change in the class timetable, or necessity to move classrooms is, in fact, troublesome and takes up the time which should be spent on teaching.

- Electricity breakdowns or other emergency situations may render the board unusable.

Obviously, the difficulties mentioned above are not inherent properties of the device but they may happen due to external organizational problems or some other situations in the school. Such factors hinder the educational process, yet, it is impossible to avoid them in a teacher's everyday practice, and that is the reason why they are mentioned here.

\section{Concluding remarks}

The subject of the present paper is too broad to be dealt with in great detail concerning the limitations of the space. It has to be noted, however, that the interest in and demand for interactive whiteboards are increasing. It also seems right to say that today's novelties may become obsolete tomorrow, so it is only natural to expect that new devices will appear. They may be developments of existing devices, or completely new designs, which is difficult to predict. Regardless of the technological advancement of the current or future devices, teachers will always be most interested in their practical applications. The main purpose of the didactic process is to transfer as much knowledge as possible, in the most effective and fastest way, activating the learner to perform tasks individually and thereby raising his/her interest in the subject, helping to acquire the knowledge permanently. Like other subjects of academic research, didactics also follows 
Pobrane z czasopisma Annales AI- Informatica http://ai.annales.umcs.pl

Data: 26/04/2023 16:57:22

the changes in the social environment and its range of interest concerns meeting current requirements in the field of education.

The paper mentions the issue of lifelong learning in a rather cursory way, though it should perhaps be a subject of a separate, more extensive analysis. Lifelong learning is a significant element of the education system. It satisfies the needs arising out of the constant social and economic changes occurring in the world. Today, the technology of communication, understood broadly as exchanging information seems to be of outmost importance both at the interpersonal level and the technological level. The interactive whiteboard is but an example of changes occurring in the school, a technological response to growing expectations and challenges.

The interactive whiteboard offers a wide spectrum of educational tools, thanks to which it can be applied for various purposes - in classroom teaching, training sessions, presentations, distance learning, teleconferences. It will be useful for instructors and specialists presenting the results of their work (architects, engineers, military strategists or advisers of emergency committees). Institutions which can profit from using interactive whiteboards include schools, universities, training companies, advertising agencies, corporations, conference centers, government agencies and the army.

The examples discussed above show a wide array of possible applications of interactive whiteboards in various domains of life. At present, the vast majority of all interactive whiteboards that have been purchased in Poland are to be found in schools, universities, teachers' advisory centers and other educational institutions ${ }^{7}$.

\section{References}

[1] Prauzner T., Nauczanie na odległość - nowa metoda zdobywania wiedzy, Materiały pokonferencyjne, V Konferencja naukowo-techniczna nt. Technologiczne systemy informacyjne w inżynierii produkcji i kształceniu technicznym (Wyd. Lubelskie Towarzystwo Naukowe, Kazimierz Dolny, 2003): 17-24.

[2] Prauzner T., Wykorzystanie mediów elektronicznych w edukacji elektronicznej studentów, Materiały pokonferencyjne Uniwersytetu Rzeszowskiego, IV Konferencja nt. Technika - Informatyka - Edukacja (Iwonicz Zdrój, 2006): $140-145$.

[3] Prauzner T., Prauzner M., Rozwój techniki i jej wpływ na powstawanie nowoczesnych środków nauczania, Materiały pokonferencyjne, VIII Konferencja naukowo-techniczna nt. Technologiczne systemy informacyjne w inżynierii produkcji i kształceniu technicznym (Wyd. Lubelskie Towarzystwo Naukowe, Kazimierz Dolny, 2007): 133.

[4] Prauzner T., Mass media w ujęciu pedagogicznym, Materiały pokonferencyjne, V Międzynarodowa Konferencja Naukowa nt. Technika - Informatyka - Edukacja (Wyd. Uniwersytetu Rzeszowskiego, Iwonicz Zdrój, 2007): 108-112.

${ }^{7}$ http://www.e-mentor.edu.pl/artykul_v2.php?numer $=18 \&$ id $=383$ 
[5] Prauzner T., Aktywność komunikacyjna studentów i nauczyciela w kształceniu elearning, Materiały pokonferencyjne, VI Międzynarodowa Konferencja Naukowa nt. Technika - Informatyka - Edukacja (Wyd. Uniwersytetu Rzeszowskiego, Iwonicz Zdrój, 2008): 160-165.

[6] Prauzner T., Barski T., Rola nowoczesnych środków nauczania w zmieniającej się szkole, Materiały pokonferencyjne, Technice Vzdelenie Ako Sucast Vseobecneho Vzdelania (Velka Lomnica, 2003).

[7] Prauzner T., Zastosowanie komputera w edukacji - problemy psychologiczne, Wychowanie Techniczne w Szkole 5 (Agencja Wydawnicza BiS, Warszawa, 2004): 14-16.

[8] Prauzner T., Zastosowanie programów symulacyjnych w nauczaniu przedmiotów technicznych, Prace Naukowe Akademii im. Jana Długosza w Częstochowie (Wyd. AJD, Częstochowa, 2006): 121-128.

[9] Prauzner T., Wartości pedagogiczne w ujęciu komputeryzacji procesu nauczania, Prace Naukowe Wyższej Szkoły Pedagogicznej, Wychowanie Techniczne (Wyd. WSP, Częstochowa, 2006).

[10] Bartoszewicz M., Skuteczność edukacyjna wizualizacji wybranych zagadnień chemicznych, PhD thesis, Zakład Dydaktyki Chemii (unpublished, 2006, in Polish).

[11] Gulińska H., Bartoszewicz M., Scenariusze lekcji przyrody prowadzonych z wykorzystaniem tablicy StarBoard (TIK Oficyna Wydawnicza CDiDN, Szczecin, 2006).

[12] Gulińska H., Bartoszewicz M., Tablica interaktywna na lekcjach przyrody-wyniki badań (Oficyna Wydawnicza CDiDN, Szczecin, 2005).

[13] Gulińska H., Bartoszewicz M., Salamońska A., Tablica interaktywna StarBoard jako nowy element w kształceniu zdalnym, Technologia Informacyjna i Komunikacyjna w Edukacji, Nowoczesne Narzędzia TI (Oficyna Wydawnicza CDiDN, 2006).

[14] Olczak J., Nowoczesne narzędzia technologii informacyjnej (Oficyna Wydawnicza CDiDN, Szczecin, 2005).

[15] Siemieniecki B., Komputer w edukacji. Podstawowe problemy technologii informacyjnej (Wyd. Uniwersytet M. Kopernika, Torun, 1998).

[16] Szołno A., Nowoczesna technika wspomaga mobilnych, Biuletyn OHP (Wyd. Lubuska WK OHP, 2006).

[17] Wodecki A., Kto wie, kim będę jutro? Kilka luźnych refleksji o e-learningu, Oracle iLearning.

[18] Żołędziowski D., Wizualizacja wybranych mechanizmów reakcji polimeryzacji, polikondensacji i depolimeryzacji MCS thesis, Zakład Dydaktyki Chemii, Wydział Chemii UAM (unpublished, 2005, in Polish).

[19] Laboratorium Edukacji Multimedialnej, http://www.lem.codn.edu.pl $/$ page $=\operatorname{art} \& \operatorname{cid}=22$. 